Dr. Scott reached Addis Ababa on August 20, 1948 ; but the unusually heavy rains had done so much damage to the roads he wished to traverse that he was not able to start until October 15. $\mathrm{He}$ returned to the capital on January 28, 1949, after a remarkable journey, with no European companion, which took him to within about seventy miles of the Kenya border. His main objective was the high ground west of the Rift Valley, Mt. Damota (10,400 ft.) and the almost legendary Gughé Highlands, rising to $13,780 \mathrm{ft}$. $\mathrm{He}$ continued south through Konso to Yavello and returned to his base up the eastern side of the Rift. It is pleasant to record that on his 1948-49 journey Dr. Scott found public security much better than it had been when he was travelling in the country during 1926-27.

The account of the journey is prefaced by a section on "Biogeographical Considerations", in which Dr. Scott briefly considers the "zones of vegetation in southern Ethiopia" (with special reference to those on the mountains he personally explored) in relation to published information about the biology of mountain country elsewhere in Africa. In this connexion he discusses certain groups of Coleoptera in which he is a specialist; and also the effects of isolation on the evolution of congeneric species, together with the parallel evolution of certain insects along with the high-mountain plants with which they are so closely associated.

Although his main task in Ethiopia was the collection of observations on and specimens of insects, Dr. Hugh Scott made a most useful botanical collection. Hitherto, nothing much was known of the vegetation of Mt. Damota and the Gughé Highlands, and no collections of plants from these mountains had ever been made. Dr. Scott is to be congratulated on bringing home many plant specimens in such an excellent state of preservation that one might have imagined that they had been taken and prepared under ideal conditions. This, however, is far from the truth, for much of the time that he was at high altitudes, Dr. Scott was working under very austere and unpleasant conditions. The Gughé Highlands in particular are notoriously wet. That Dr. Scott endured "raw, damp weather, with thunder on two nights" when camping at about $10,600 \mathrm{ft}$. on Mt. Tola, is certainly not reflected in the specimens he obtained.

Botanically the chief interest in the collection is that it comes from an area situated between the Simien Highlands, so well collected by German and French collectors in the first half of the past century, and the highlands of Kenya, the flora of which is now comparatively well known. When Dr. Scott's plant collections are finally worked out, the preliminary determinations of which are listed at the end of his paper, many gaps in our knowledge of the distribution of plants on the mountains of Africa will have been filled.

About half the paper is taken up with the "Description of the Country, with Natural History Notes", to which are added three appendixes. The most important of these deals with the author's archæological and ethnological observations, with special reference to the phallic monoliths of Walamo and Sidamo. 'These exist in thousands, many of them up to ten feet in height, yet they are very little known. In his main narrative Dr. Scott gives full rein to his very wide natural history and human interests. They range from the Addis Ababa gardens, and the butterflies and birds that frequent them, to the spread of prickly pear, the practices of the local bee-keepers and the uses made of the local bamboos. He found almost everywhere that extensive inroads had been made into the native vegetation, and that in places cultivation had been carried right up to $10,000 \mathrm{ft}$. Yet in parts of the south, splendid primary forests still exist. He gives, of course, special importance in his narrative to the mountain massifs that were his principal objective; "and anyone who has had the good fortune to be a pioneer in any brench of biological exploration in an unknown locality will live again with him the enthusiasm with which he toiled up those distant slopes.

R. E. MOREaU

E. Mulne-Redhead

\section{GRAZING BEHAVIOUR OF BULLOCKS}

$\mathrm{E}$ NVIRONMENTAL factors which can influence the behaviour of a herd of bullocks may be divided into, first, the natural conditions of climate, including seasonal changes and weather; and secondly, the system of management of the bullocks.

Methods of management, the ways in which grass, in different quantities and of varying quality and palatability, is offered to the beasts, fall into two categories. The grazing may be uninterrupted from day to day, as in free-range and rotational systems. Other methods exercise some form of daily control over the quantity of herbage allowed the bullocks, which may be a control of area or of time allowed on the grass. In a recent article, J. C. Tayler, of the Grassland Research Station, Stratford-on-Avon, has described the behaviour of Hereford-cross bullocks under two management systems in these categories (Brit. J. Animal Behaviour, 1, No. 2; April 1953).

These studies have shown that the grazing behaviour of bullocks in a herd may be regarded as following a repeated daily pattern closely related to environmental factors. Of these factors, the varying hours of daylight throughout the year produce seasonal changes in the basic pattern. Weather and other disturbances may affect the grazing pattern in many minor ways ; but, next to seasonal effects, those resulting from the system of management seem to be the most important.

Under the two systems of management, 'rotational' and 'strip' grazing, changes in behaviour resulting from the system may be due to the herbage, through its physical, internal effect as, for example, in winter grazing on limited areas. They may also be due to a daily disturbance as was shown in the 'strip folding' system. Under this system of management the animals show definite signs of appreciating that a fresh supply of grass will be offered later in the morning and delay their main grazing period up to six hours later than it would occur under undisturbed conditions.

Studies of behaviour during the past three years have been used at the Grassland Research Station for improving the accuracy of results in live-weightincrease experiments where bullocks are weighed straight from pasture. A knowledge of their behaviour pattern makes it possible to remove the bullocks from pasture for weighing when the 'fill' of grass in the rumen is approximately the same at each weighing. 